\title{
Corrigendum: The Authenticity Scale: Validation in Russian Culture
}

\author{
Sofya Nartova-Bochaver ${ }^{1 *}$, Sofia Reznichenko ${ }^{1}$ and John Maltby ${ }^{2}$ \\ ${ }^{1}$ School of Psychology, National Research University Higher School of Economics, Moscow, Russia, ${ }^{2}$ College of Medicine, \\ Biological Sciences and Psychology, University of Leicester, Leicester, United Kingdom
}

Keywords: Authenticity Scale, wellbeing, validation, reliability, Russian culture

\section{A Corrigendum on}

\section{OPEN ACCESS}

Edited and reviewed by:

Sai-fu Fung,

City University of Hong Kong,

Hong Kong

${ }^{*}$ Correspondence:

Sofya Nartova-Bochaver

s-nartova@yandex.ru;

snartovabochaver@hse.ru

Specialty section:

This article was submitted to

Quantitative Psychology and

Measurement

a section of the journal

Frontiers in Psychology

Received: 04 March 2021

Accepted: 19 March 2021

Published: 20 April 2021

Citation:

Nartova-Bochaver S, Reznichenko S and Maltby J (2021) Corrigendum:

The Authenticity Scale: Validation in Russian Culture.

Front. Psychol. 12:675919.

doi: 10.3389/fpsyg.2021.675919
The Authenticity Scale: Validation in Russian Culture

by Nartova-Bochaver, S., Reznichenko, S., and Maltby, J. (2021). Front. Psychol. 11:609617. doi: 10.3389/fpsyg.2020.609617

In the original article, there was a mistake in Figure 3 "The optimal CFA model tested for the Authenticity Scale compared with the original model (Wood et al., 2008)." as published. Near the item 1, which is included in Acceptance External Influence subscale, the sign "-" was mistakenly put. It should be removed. The corrected Figure 3 "The optimal CFA model tested for the Authenticity Scale compared with the original model (Wood et al., 2008)" appears below.

In the original article, there was also a mistake in the Appendix table "The Authenticity Scale: Original, Russian, and Corresponding English Versions" as published. The text of Item 1 (both English and Russian Wording) was incorrectly highlighted in bold. The text should be in normal (regular) style. The corrected Appendix table "The Authenticity Scale: Original, Russian, and Corresponding English Versions" appears below.

The authors apologize for these errors and state that they do not change the scientific conclusions of the article in any way. The original article has been updated.

\section{Appendix}

The Authenticity Scale: Original, Russian, and corresponding English versions.

Инструкция:

Пожалуйста, прочтите список приведенных утверждений и оцените их с точки зрения того, насколько они характеризуют Ваши привычки и поведение. Поставьте галочку в ячейке под тем ответом, который подходит Вам.

Instruction:

Please read the list of statements provided and rate them in terms of how they characterize your habits and behavior. Please tick the answer that best describes you. 


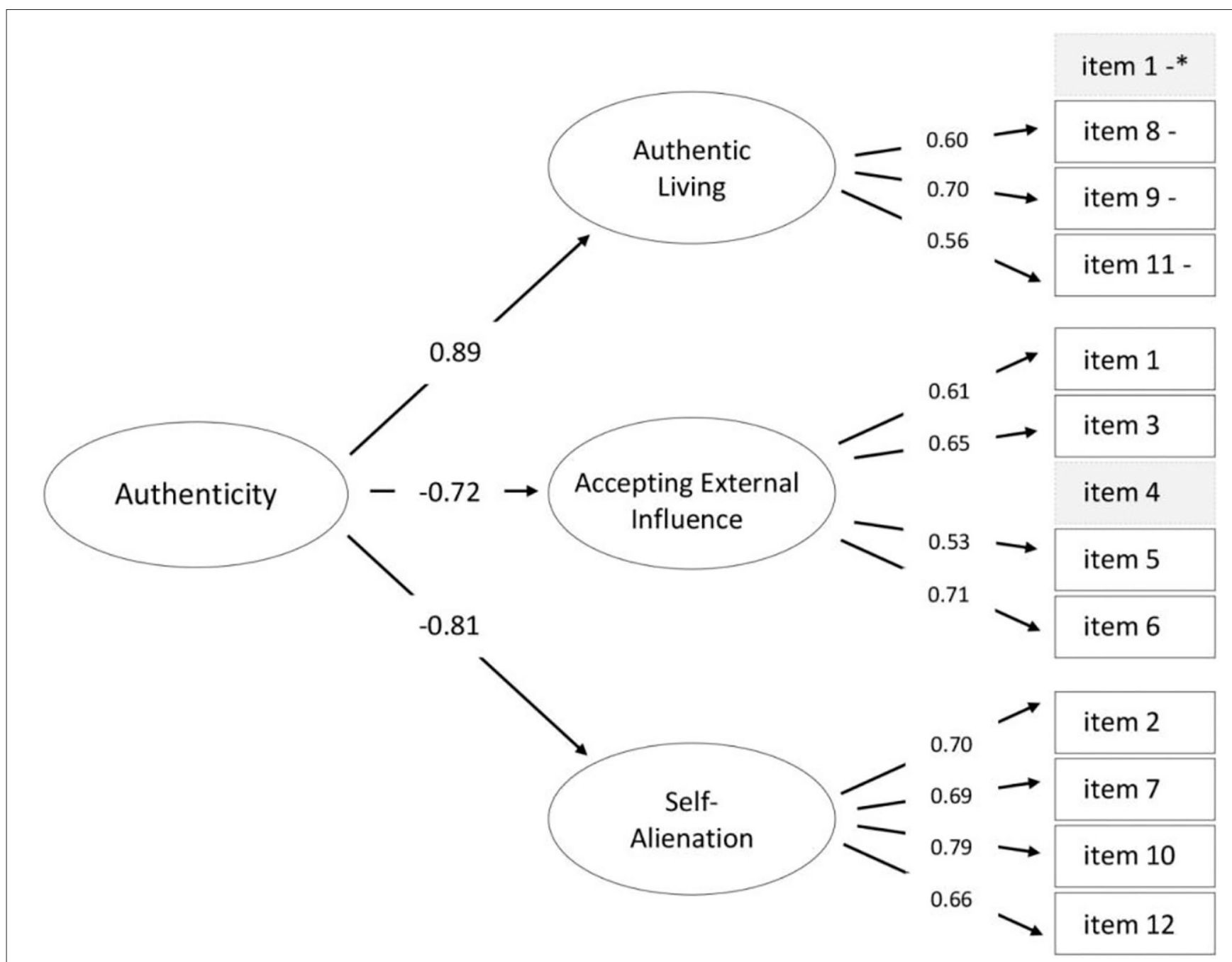

FIGURE 3 | The optimal CFA model tested for the Authenticity Scale compared with the original model (Wood et al., 2008). Blocks dotted gray indicate excluded items. " - item one was included in Accepting External Influence. "-" indicates negatively phrased items. Error variances omitted for clarity.

\section{REFERENCES}

Wood, A. M., Linley, P. A., Maltby, J., Baliousis, M., and Joseph, S. (2008). The authentic personality: a theoretical and empirical conceptualization and the development of the authenticity scale. J. Counsel. Psychol. 55, 385-399. doi: 10.1037/0022-0167.55. 3.385
Copyright (๑) 2021 Nartova-Bochaver, Reznichenko and Maltby. This is an openaccess article distributed under the terms of the Creative Commons Attribution License (CC BY). The use, distribution or reproduction in other forums is permitted, provided the original author(s) and the copyright owner(s) are credited and that the original publication in this journal is cited, in accordance with accepted academic practice. No use, distribution or reproduction is permitted which does not comply with these terms. 


\section{APPENDIX}

\begin{tabular}{|c|c|c|c|}
\hline $\begin{array}{l}\text { Item } \\
\text { code }\end{array}$ & $\begin{array}{l}\text { The original Authenticity Scale (Wood } \\
\text { et al., 2008) }\end{array}$ & $\begin{array}{l}\text { The Russian version of the Authenticity } \\
\text { Scale } \\
\text { English wording }\end{array}$ & $\begin{array}{l}\text { The Russian version of the } \\
\text { Authenticity Scale } \\
\text { Russian wording }\end{array}$ \\
\hline 1 & $\begin{array}{l}\text { I think it is better to be yourself than to be } \\
\text { popular (AL) }\end{array}$ & $\begin{array}{l}\text { I think it is better to be popular than to be } \\
\text { yourself (AEI) }\end{array}$ & $\begin{array}{l}\text { Для меня важнее понравиться другим, чем } \\
\text { «оставаться самим собой (ПВВ) }\end{array}$ \\
\hline 2 & I don't know how I really feel inside (SA) & I don't know how I really feel inside (SA) & $\begin{array}{l}\text { Я не знаю, что я чувствую на самом деле } \\
(\mathrm{CO})\end{array}$ \\
\hline 3 & $\begin{array}{l}\text { I am strongly influenced by the opinions of } \\
\text { others (AEI) }\end{array}$ & $\begin{array}{l}\text { I am strongly influenced by the opinions of } \\
\text { others (AEI) }\end{array}$ & $\begin{array}{l}\text { Мои поступки и взгляды меняются в } \\
\text { зависимости от мнения других (ПВВ) }\end{array}$ \\
\hline 4 & $\begin{array}{l}\text { I usually do what other people tell me to do } \\
\text { (AEI) }\end{array}$ & $\begin{array}{l}\text { I usually do what other people tell me to do } \\
\text { (Deleted) }\end{array}$ & $\begin{array}{l}\text { Обычно я делаю то, о чем меня просят } \\
\text { другие (Deleted) }\end{array}$ \\
\hline 5 & $\begin{array}{l}\text { I always feel I need to do what others expect } \\
\text { me to do (AEI) }\end{array}$ & $\begin{array}{l}\text { I always feel I need to do what others expect } \\
\text { me to do (AEI) }\end{array}$ & $\begin{array}{l}\text { Я считаю, что должен делать то, чего от } \\
\text { меня ждут другие (ПВВ) }\end{array}$ \\
\hline 6 & Other people influence me greatly (AEI) & Other people influence me greatly (AEI) & $\begin{array}{l}\text { Окружающие очень сильно влияют на меня } \\
\text { (ПВВ) }\end{array}$ \\
\hline 7 & I feel as if I don't know myself very well (SA) & I feel as if I don't know myself very well (SA) & $\begin{array}{l}\text { Мне кажется, что я не знаю себя } \\
\text { достаточно хорошо (CO) }\end{array}$ \\
\hline 8 & I always stand by what I believe in (AL) & $\begin{array}{l}\text { I do not always succeed in upholding what } \\
\text { I believe in }(A L)\end{array}$ & $\begin{array}{l}\text { Мне не всегда удается отстоять то, во что я } \\
\text { верю (Ж) }\end{array}$ \\
\hline 9 & I am true to myself in most situations (AL) & $\begin{array}{l}\text { I can't say that I am true to myself in most } \\
\text { situations }(A L)\end{array}$ & $\begin{array}{l}\text { Не могу сказать, что я всегда бываю верен } \\
\text { себе (Ж) }\end{array}$ \\
\hline 10 & I feel out of touch with the "real me" (SA) & I feel out of touch with the "real me" (SA) & $\begin{array}{l}\text { Я чувствую, что я не в контакте с } \\
\text { «истинным Я» }(\mathrm{CO})\end{array}$ \\
\hline 11 & $\begin{array}{l}\text { I live in accordance with my values and beliefs } \\
\text { (AL) }\end{array}$ & $\begin{array}{l}\text { I don't live in accordance with my values } \\
\text { and beliefs }(A L)\end{array}$ & $\begin{array}{l}\text { Мне трудно жить в соответствии с моими } \\
\text { ценностями убеждениями (Ж) }\end{array}$ \\
\hline 12 & I feel alienated from myself (SA) & I feel alienated from myself (SA) & Я кажусь незнакомцем самому себе (CO) \\
\hline
\end{tabular}

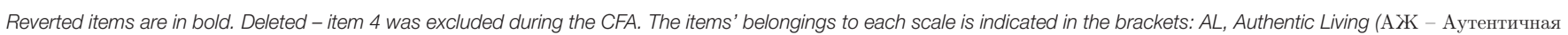
жизнь); AEl, Accepting External Influence (ПВВ - Принятие внешнего влияния); SA, Self-Alienation (СО - Самоотчуждение).

Responses were made on a seven-point scale: from 1 (не относится ко мне вообще; does not describe me at all) to 7 (полностью относится ко мне; describes me very well). 